\title{
WOODY COMPONENT STRUCTURE OF A RIPARIAN FOREST IN AN INTERMITTENT STREAM IN THE SEMI-ARID REGION OF PARAÍBA, BRAZIL
}

\author{
Alecksandra Vieira de Lacerda ${ }^{1 *}$, Francisca Maria Barbosa ${ }^{2}$ \\ ${ }^{1 *}$ Federal University of Campina Grande, Academic Unit for Development Technology, Sumé, Paraíba, Brazil - alecvieira@yahoo.com.br \\ ${ }^{2}$ National Institute of Science and Technology, João Pessoa, Paraíba, Brazil - fmariabarbosa@yahoo.com.br \\ Received for publication: 25/01/2019 - Accepted for publication: 12/07/2019
}

\begin{abstract}
Resumo
Estrutura do componente lenhoso da mata ciliar em riacho intermitente no semiárido paraibano, Brasil. Objetivou-se analisar os aspectos estruturais da vegetação ciliar de um curso d’água intermitente no semiárido paraibano. Foram estabelecidas 51 parcelas contíguas de 10 X $20 \mathrm{~m}$ (1,02 ha), distribuídas em três faixas paralelas ao longo do curso d'água. Utilizou-se como critérios de inclusão amostrar os indivíduos arbustivo-arbóreos, vivos e mortos ainda em pé, com diâmetro do caule ao nível do solo (DNS) $\geq 3 \mathrm{~cm}$ e altura total $\geq 1 \mathrm{~m}$. Na área foram amostrados 1.864 indivíduos, com área basal total de $14,8 \mathrm{~m}^{2}$. As três espécies mais importantes em VI foram: Cenostigma pyramidale (Tul.) E. Gagnon \& G.P. Lewis, Combretum leprosum Mart. e Croton blanchetianus Baill. A altura e o diâmetro médio dos indivíduos amostrados foram respectivamente: $4,8 \mathrm{~m}$ e $10,1 \mathrm{~cm}$. Os valores de diversidade e equabilidade foram 2,77 nats.ind.$^{-1}$ e 0,72 respectivamente.

Palavras-Chave: Fitossociologia, vegetação ripária, ecossistema ribeirinho, Caatinga.
\end{abstract}

\begin{abstract}
This study aimed to analyze the riparian vegetation structural aspects of an intermittent watercourse in the semiarid region of Paraíba, Brazil. Fifty-one contiguous plots of 10 x 20 m (1.02 ha) were established and distributed in three parallel strips along a watercourse. Living and dead shrub-tree specimens still standing, with stem diameter at ground level (DGL) $\geq 3 \mathrm{~cm}$ and total height $\geq 1 \mathrm{~m}$, were considered as inclusion criteria. A total of 1,864 specimens with a total basal area of $14.8 \mathrm{~m}^{2}$ were sampled in the study area. Cenostigma pyramidale (Tul.) E. Gagnon \& G.P. Lewis, Combretum leprosum Mart. and Croton blanchetianus Baill were the most important species (IV). The average height and diameter of the sampled plants were $4.8 \mathrm{~m}$ and $10.1 \mathrm{~cm}$, respectively, and diversity and equability values were 2.77 nats.ind. ${ }^{-1}$ and 0.72 , respectively.

Keywords: Phytosociology, riparian vegetation, riverside ecosystem, Caatinga.
\end{abstract}

\section{INTRODUCTION}

Forests associated with water bodies have demonstrated their ecological and social relevance throughout the years. According to Oliveira et al. (2009), riparian forests are represented by vegetation that develops along watercourses. These plant formations vary in floristic composition and community structure resulting from interactions between aquatic and terrestrial (adjacent) ecological systems (RODRIGUES; LEITÃO FILHO, 2009).

Considering the ecological functions, riparian vegetation plays a variety of roles, serving as a refuge for aquatic and terrestrial biota, protecting rivers and influencing water quality, contributing to the maintenance of the hydrological cycle in hydrographic basins. In an associated way, it is defined as an ecological corridor and its presence is fundamental for the maintenance of gene flow between nearby communities (BRACKMANN; FREITAS, 2013). Some authors such as Avila et al. (2011) also consider that riparian forests promote the preservation of river water sources, which have an important social and ecological function for public supply, irrigation, industrial use, biodiversity preservation, and maintenance of ecological balance.

Riparian ecosystems in areas of Caatinga have a higher level of humidity and are mainly characterized by a composition of tree species (LACERDA; BARBOSA, 2018). In the Caatinga biome, riparian forests are defined as those adjacent to intermittent or ephemeral streams. Thereby, in this region, even considering the legal protection factor and the importance of these areas, these forests have a significant degree of degradation. Therefore, phytosociological studies on riparian ecosystems in areas of Caatinga are relevant to support strategies for conservation and restoration of degraded environments.

According to Jardim et al. (2008), structural analyses are of utmost importance for the applicability of forest management and restoration strategies, so it is necessary to know the floristic composition and structural aspects of the vegetation because based on this knowledge, it is possible to deduce the origin, ecological and synecological characteristics, and dynamics and trend for future forest development. Chaves et al. (2013) explain that phytosociology is a study of all phenomena related to vegetation within social units, relating the plant, soil and climate complex.

FLORESTA, Curitiba, PR, v. 50, n. 3, p. 1565 - 1574, jul/set 2020.

Lacerda, A. V. et.al.

ISSN eletrônico 1982-4688

DOI: $10.5380 /$ rf.v50 i3. 64520 
Thus, this study aimed to analyze the riparian vegetation structural aspects in an intermittent watercourse in the semi-arid region of Paraíba, northeast Brazil.

\section{MATERIAL AND METHODS}

This research was conducted in the Taperoá river basin in the semi-arid region of Paraíba, Brazil (Figure 1), located in the central part of Paraíba State $\left(6^{\circ} 51^{\prime} 31^{\prime \prime}\right.$ and $7^{\circ} 34^{\prime} 21^{\prime \prime} \mathrm{S}$ latitude and $36^{\circ} 0^{\prime} 55^{\prime \prime}$ and $37^{\circ} 13^{\prime} 9^{\prime \prime} \mathrm{W}$ longitude) (LACERDA; BARBOSA, 2018). The climate in this region is BSwh, hot semi-arid, which indicates a dry climate, according to the Köeppen classification. Regarding geology, it is defined as a predominantly crystalline structure, which makes up the Precambrian shield of northeastern Brazil. Considering the geomorphology, this basin is located in the eastern escarpment of the Borborema Plateau, in the extensive pediplain areas in the Sertão region of Brazil. The relief has flat, smooth wavy, wavy, strong wavy, and mountainous areas. The vegetation types dominant in this area are classified as those from Savanna-Steppe floristic region (IBGE, 2012).

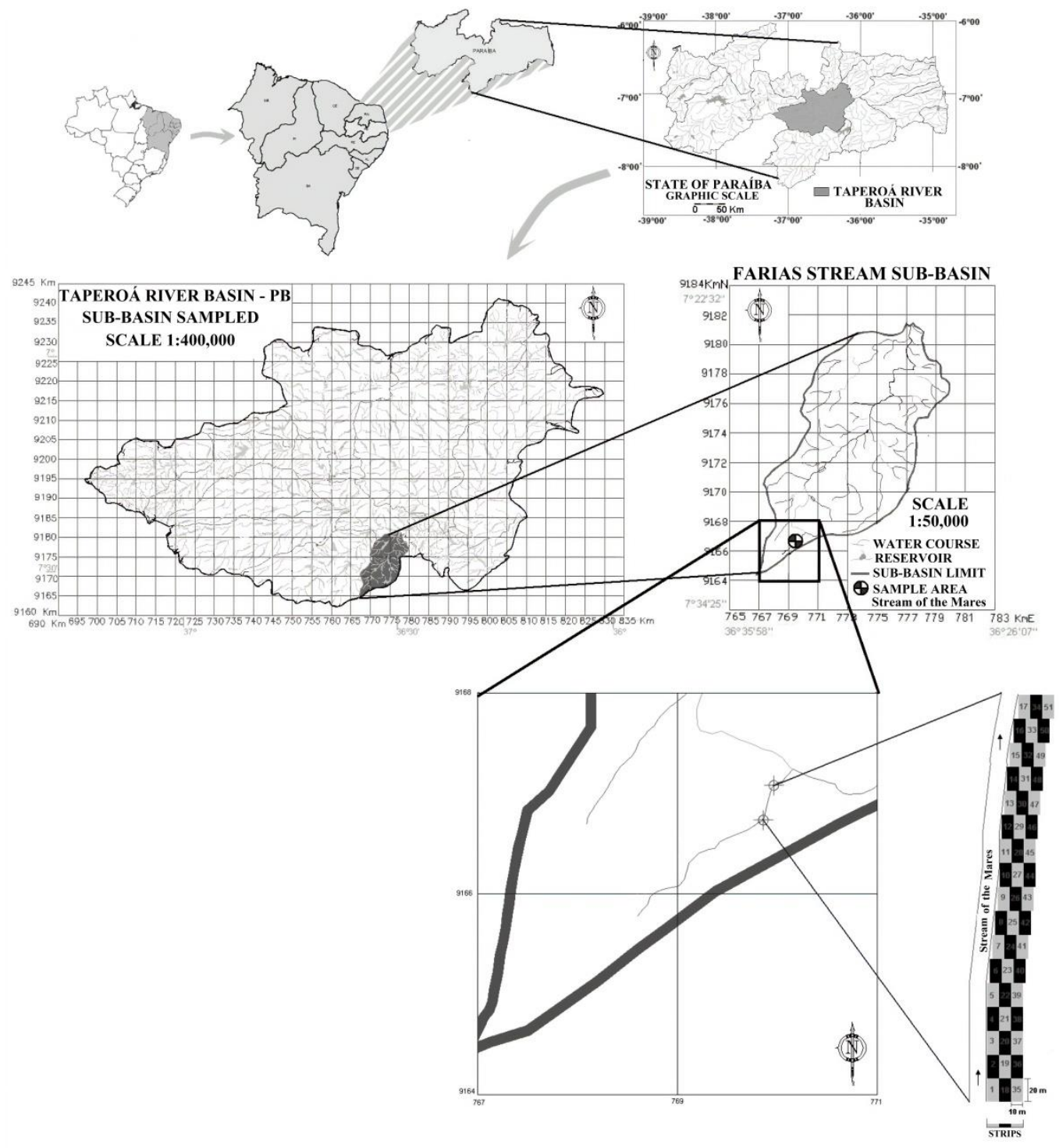

Source: Adapted from Lacerda and Barbosa (2018)

Figure 1. Location of the riparian forest in the Stream of the Mares, sampled in the Taperoá river basin, semi-arid region of Paraíba, Brazil.

Figura 1. Localização da área de mata ciliar do riacho dos Mares amostrada na bacia hidrográfica do rio Taperoá, semiárido paraibano.

FLORESTA, Curitiba, PR, v. 50, n. 3, p. 1565 - 1574, jul/set 2020

Lacerda, A. V. et.al.

ISSN eletrônico 1982-4688

DOI: 10.5380/rf.v50 i3. 64520 
In the hydrographic basin, vegetation was sampled in the Stream of the Mares riparian forest (Figure 1). This intermittent stream is located in the municipality of São João do Cariri and is about $12 \mathrm{~km}$ long, with a drainage area of $33 \mathrm{~km}^{2}$, within the boundaries of the Farias stream sub-basin. The riparian area studied in this watercourse ( $3.4 \mathrm{ha}$ ) is between $7^{\circ} 31^{\prime} 53^{\prime \prime}$ and $7^{\circ} 31^{\prime} 38^{\prime \prime} \mathrm{S}$ latitude and between $36^{\circ} 33^{\prime} 39^{\prime \prime}$ and $36^{\circ} 33^{\prime} 06^{\prime \prime}$ W longitude. In this stretch, the stream is known by the riverine population as Avelós stream, a narrow channel with about $7 \mathrm{~m}$ width, on average, and altitude ranging from 536 to $550 \mathrm{~m}$.

For the analysis of plant community structure, fifty-one contiguous plots of $10 \times 20 \mathrm{~m}$ (1.02 ha) were established and distributed in three parallel bands along the studied watercourse (Figure 1). All living and dead shrub-tree specimens, still standing, with stem diameter at ground level (DGL) $\geq 3 \mathrm{~cm}$ and total height $\geq 1 \mathrm{~m}$, were sampled. The specimens were marked with small plaques, numbered and identified, and their perimeter at ground level and height were recorded. The perimeter was recorded using a tape measure and later converted to diameter. For trees and shrubs with multiple stems, all branches with DGL $\geq 3 \mathrm{~cm}$ were measured. The height was determined using a $5 \mathrm{~m}$ pole, and the height of the highest specimens was estimated by comparison with this pole. The collector curve was used to assess the sufficiency of the number of plots by plotting the accumulated number of new unsampled species in each plot. The point where the curve tends to stabilize represents the minimum area of floristic sampling (CAIN; CURTIS, 1959).

Phytosociological parameters were calculated using the MATA NATIVA 4 software (CIENTEC, 2016). The following data were analyzed: number of species, absolute and relative densities (AD and RD), absolute and relative frequencies (AF and RF), and absolute and relative dominances (ADo and RDo) (MUELLER-DOMBOIS; ELLENBERG, 1974). Considering the relative parameters, the importance value (IV) and the coverage value (CV) were subsequently calculated for each species. Shannon's specific diversity (H') and equability (J') indices were used to assess floristic heterogeneity, according to Magurran (1988) and Pielou (1975), respectively, based on the proportional abundance of species.

Frequency distribution histograms with $1 \mathrm{~m}$ interval and $3 \mathrm{~cm}$ interval were used to assess height distribution and diameter classes of the sampled specimens, respectively. For species with more than $10 \%$ of the total number of specimens, distribution graphs based on diameter and height classes were made considering the abovementioned intervals. Fertile specimens of each species were collected, herborized and deposited in the Lauro Pires Xavier Herbarium (JPB) of the Federal University of Paraíba. The species were classified into families according to the APG III (2009) system and the taxonomic update of the species and their authors followed the List of Brazilian Flora Species (REFLORA, 2016).

\section{RESULTS}

Analyzing the cumulative curve of additional species, considering the real order of the plots, in the Stream of the Mares, there was a progressive appearance of new species until the $29^{\text {th }}$ plot. Nevertheless, from this plot, it was observed a less inclined curve and only three new species were included, as follows: Allophylus quercifolius (Mart.) Radlk in the $47^{\text {th }}$ plot and Mimosa tenuiflora (Willd.) Poir. and Pseudobombax marginatum (A.St.-Hil., Juss. \& Cambess.) A.Robyns in the $51^{\text {st }}$ plot (Figure 2). Thus, the curve inclination pattern, tending to be parallel with the horizontal axis from plot 29 , indicates a stabilization process as the number of plots increases.

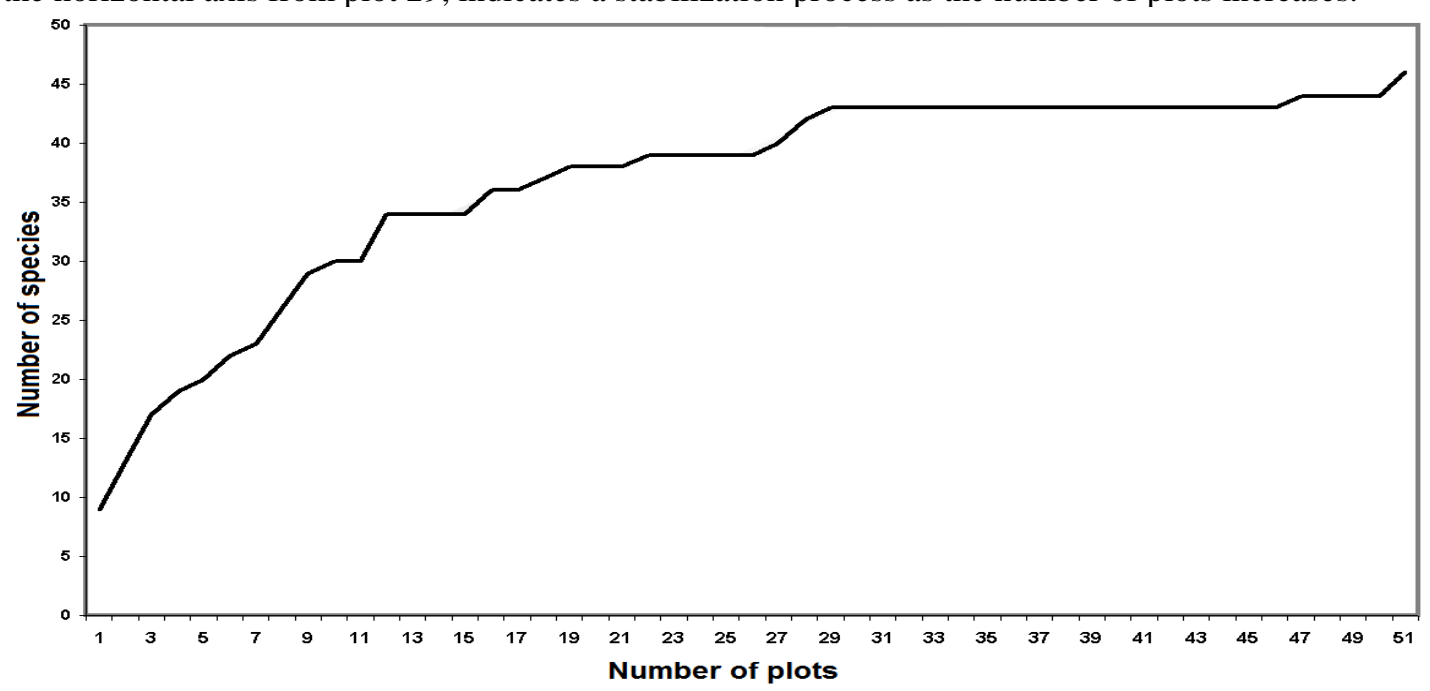

Figure 2. Sample sufficiency curve of shrub-tree species in relation to the riparian area sampled in the Stream of the Mares, semi-arid region of Paraíba, Brazil.

FLORESTA, Curitiba, PR, v. 50, n. 3, p. 1565 - 1574, jul/set 2020.

Lacerda, A. V. et.al.

ISSN eletrônico 1982-4688

DOI: $10.5380 /$ rf.v50 i3. 64520 
Figura 2. Curva de suficiência amostral de espécies arbustivo-arbórea em relação à área ciliar amostrada no riacho dos Mares, semiárido paraibano.

A total of 1,574 living and 290 standing dead specimens were sampled in the phytosociological survey of shrub and tree stratum in the Stream of the Mares. Living specimens were represented by 22 families, 39 genera and 46 species. Considering all sampled trees and shrubs, a total density of 1,827 specimens per hectare and a total basal area of $14.8 \mathrm{~m}^{2}$ were recorded.

Regarding the identified families, Euphorbiaceae, Combretaceae, Fabaceae, and Cactaceae stood out, accounting for $86.2 \%$ of the number of living specimens sampled. Euphorbiaceae, Combretaceae, Fabaceae, and Burseraceae had the highest IV. Combretum leprosum Mart., Croton blanchetianus Baill., Cenostigma pyramidale (Tul.) E. Gagnon \& G.P. Lewis, Manihot glaziovii Müll.Arg., Combretum monetaria Mart., Croton echioides Baill., Luetzelburgia auriculata (Allemão) Ducke, and Mimosa ophthalmocentra Mart. ex Benth were the most prominent species, considering the total number of living specimens. These eight species represented $74.40 \%$ of the living specimens recorded. The species and their respective phytosociological parameters in decreasing order of IV are shown in Table 1.

Table 1. Phytosociological parameters in decreasing order of importance value (IV) of tree and shrub species sampled in the riparian forest of the Stream of the Mares in the Taperoá river basin, semi-arid region of Paraíba, Brazil.

Tabela 1. Parâmetros fitossociológicos em ordem decrescente do valor de importância (VI) das espécies arbóreas e arbustivas amostradas na mata ciliar do riacho dos Mares na bacia do rio Taperoá, semiárido paraibano.

\begin{tabular}{|c|c|c|c|c|c|c|c|c|c|}
\hline SPECIES & $\mathbf{C N}$ & $\begin{array}{c}\text { AD } \\
\text { (ind./ha) }\end{array}$ & $\begin{array}{l}\text { RD } \\
(\%)\end{array}$ & $\begin{array}{c}\text { AF } \\
(\%)\end{array}$ & $\begin{array}{l}\text { RF } \\
(\%)\end{array}$ & $\begin{array}{c}\text { ADo } \\
\text { (m2/ha) }\end{array}$ & $\begin{array}{l}\text { RDo } \\
(\%)\end{array}$ & IV & $\mathbf{C V}$ \\
\hline $\begin{array}{l}\text { Dead } \\
\text { Cenostigma pyramidale (Tul.) E. Gagnon \& }\end{array}$ & - & 284.31 & 15.56 & 100.00 & 9.83 & 1.229 & 8.483 & 33.87 & 24.04 \\
\hline G.P. Lewis & 36 & 186.27 & 10.19 & 78.43 & 7.71 & 1.808 & 12.481 & 30.38 & 22.67 \\
\hline Combretum leprosum Mart. & 82 & 307.84 & 16.85 & 82.35 & 8.09 & 0.771 & 5.319 & 30.26 & 22.16 \\
\hline $\begin{array}{l}\text { Croton blanchetianus Baill. } \\
\text { Commiphora leptophloeos (Mart.) }\end{array}$ & 39 & 208.82 & 11.43 & 76.47 & 7.51 & 0.482 & 3.325 & 22.27 & 14.75 \\
\hline J.B.Gillett. & 275 & 34.31 & 1.88 & 43.14 & 4.24 & 1.922 & 13.267 & 19.38 & 15.14 \\
\hline Manihot glaziovii Müll.Arg. & 87 & 116.67 & 6.38 & 72.55 & 7.13 & 0.703 & 4.851 & 18.36 & 11.23 \\
\hline Astronium urundeuva (M. Allemão) Engl. & 240 & 45.10 & 2.47 & 54.90 & 5.40 & 1.182 & 8.161 & 16.02 & 10.63 \\
\hline Combretum monetaria Mart. & 206 & 113.73 & 6.22 & 50.98 & 5.01 & 0.514 & 3.547 & 14.78 & 9.77 \\
\hline Luetzelburgia auriculata (Allemão) Ducke & 506 & 59.80 & 3.27 & 43.14 & 4.24 & 0.948 & 6.541 & 14.06 & 9.82 \\
\hline Croton echioides Baill. & 354 & 103.92 & 5.69 & 45.10 & 4.43 & 0.344 & 2.372 & 12.49 & 8.06 \\
\hline Mimosa ophthalmocentra Mart. ex Benth. & 99 & 50.98 & 2.80 & 45.10 & 4.43 & 0.480 & 3.313 & 10.53 & 6.11 \\
\hline Aspidosperma pyrifolium Mart. \& Zucc. & 279 & 43.14 & 2.36 & 33.33 & 3.28 & 0.646 & 4.462 & 10.10 & 6.82 \\
\hline $\begin{array}{l}\text { Anadenanthera colubrina (Vell.) Brenan } \\
\text { Pilosocereus gounellei (F.A.C.Weber) }\end{array}$ & 262 & 17.65 & 0.97 & 23.53 & 2.31 & 0.772 & 5.330 & 8.61 & 6.30 \\
\hline Byles \& Rowley & 557 & 45.10 & 2.47 & 19.61 & 1.93 & 0.292 & 2.012 & 6.41 & 4.48 \\
\hline Piptadenia stipulacea (Benth.) Ducke & 173 & 28.43 & 1.56 & 29.41 & 2.89 & 0.252 & 1.742 & 6.19 & 3.30 \\
\hline Guapira laxa (Netto) Furlan & 256 & 19.61 & 1.07 & 21.57 & 2.12 & 0.411 & 2.835 & 6.03 & 3.91 \\
\hline Sapium glandulosum (L.) Morong & 395 & 9.80 & 0.54 & 17.65 & 1.73 & 0.310 & 2.143 & 4.41 & 2.68 \\
\hline Jatropha mollissima (Pohl) Baill. & 369 & 24.51 & 1.34 & 23.53 & 2.31 & 0.056 & 0.385 & 4.04 & 1.73 \\
\hline Guettarda angelica Mart. ex Müll.Arg. & 364 & 20.59 & 1.13 & 21.57 & 2.12 & 0.086 & 0.593 & 3.84 & 1.72 \\
\hline Cereus jamacaru DC. & 558 & 6.86 & 0.38 & 11.76 & 1.16 & 0.275 & 1.898 & 3.43 & 2.27 \\
\hline Bauhinia cheilantha (Bong.) Steud. & 464 & 15.69 & 0.86 & 15.69 & 1.54 & 0.084 & 0.580 & 3.00 & 1.44 \\
\hline Pilosocereus pachycladus F.Ritter & 556 & 3.92 & 0.21 & 7.84 & 0.77 & 0.162 & 1.115 & 2.10 & 1.33 \\
\hline Amburana cearensis (Allemão) A.C.Sm. & 152 & 5.88 & 0.32 & 7.84 & 0.77 & 0.129 & 0.890 & 1.99 & 1.21 \\
\hline Lippia grata Schauer & 157 & 6.86 & 0.38 & 13.73 & 1.35 & 0.020 & 0.141 & 1.86 & 0.52 \\
\hline
\end{tabular}

FLORESTA, Curitiba, PR, v. 50, n. 3, p. 1565 - 1574, jul/set 2020

Lacerda, A. V. et.al.

ISSN eletrônico 1982-4688

DOI: 10.5380/rf.v50 i3. 64520 


\begin{tabular}{|c|c|c|c|c|c|c|c|c|c|}
\hline $\begin{array}{l}\text { Sebastiania macrocarpa Müll.Arg. } \\
\text { Cochlospermum regium (Mart. ex Schrank) }\end{array}$ & 169 & 10.78 & 0.60 & 5.88 & 0.58 & 0.069 & 0.476 & 1.64 & 1.07 \\
\hline $\begin{array}{l}\text { Pilg. } \\
\text { Chloroleucon foliolosum (Benth.) }\end{array}$ & 511 & 14.71 & 0.81 & 3.92 & 0.40 & 0.052 & 0.361 & 1.55 & 1.16 \\
\hline G.P.Lewis & 37 & 5.88 & 0.32 & 9.80 & 0.96 & 0.037 & 0.252 & 1.54 & 0.57 \\
\hline $\begin{array}{l}\text { Tabebuia aurea (Silva Manso) Benth. \& } \\
\text { Hook.f. ex S.Moore }\end{array}$ & 217 & 0.98 & 0.05 & 1.96 & 0.19 & 0.153 & 1.055 & 1.30 & 1.11 \\
\hline Cynophalla flexuosa (L.) J.Presl & 34 & 4.90 & 0.27 & 7.84 & 0.77 & 0.030 & 0.206 & 1.25 & 0.47 \\
\hline Mimosa paraibana Barneby & 138 & 4.90 & 0.27 & 5.88 & 0.58 & 0.009 & 0.065 & 0.91 & 0.33 \\
\hline Schinopsis brasiliensis Engl. & 218 & 0.98 & 0.05 & 1.96 & 0.19 & 0.094 & 0.652 & 0.90 & 0.71 \\
\hline $\begin{array}{l}\text { Erythroxylum revolutum Mart. } \\
\text { Tocoyena formosa (Cham. \& Schltdl.) }\end{array}$ & 372 & 3.92 & 0.21 & 5.88 & 0.58 & 0.007 & 0.051 & 0.84 & 0.26 \\
\hline $\begin{array}{l}\text { K.Schum. } \\
\text { Pseudobombax marginatum (A.St.-Hil., }\end{array}$ & 375 & 2.94 & 0.16 & 5.88 & 0.58 & 0.004 & 0.029 & 0.77 & 0.19 \\
\hline Juss. \& Cambess.) A.Robyns & 286 & 0.98 & 0.05 & 1.96 & 0.19 & 0.063 & 0.436 & 0.68 & 0.49 \\
\hline Allophylus quercifolius (Mart.) Radlk & 371 & 1.96 & 0.11 & 3.92 & 0.40 & 0.018 & 0.124 & 0.61 & 0.23 \\
\hline Libidibia ferrea (Mart. ex Tul.) L.P.Queiroz & 32 & 0.98 & 0.05 & 1.96 & 0.19 & 0.035 & 0.242 & 0.49 & 0.31 \\
\hline Capsicum parvifolium Sendtn. & 353 & 2.94 & 0.16 & 1.96 & 0.19 & 0.003 & 0.023 & 0.38 & 0.18 \\
\hline Mimosa tenuiflora (Willd.) Poir. & 260 & 0.98 & 0.05 & 1.96 & 0.19 & 0.012 & 0.083 & 0.33 & 0.14 \\
\hline Allamanda blanchetii A.DC. & 59 & 1.96 & 0.11 & 1.96 & 0.19 & 0.003 & 0.018 & 0.31 & 0.13 \\
\hline Monteverdia rigida (Mart.) Biral & 235 & 0.98 & 0.05 & 1.96 & 0.19 & 0.007 & 0.048 & 0.29 & 0.10 \\
\hline $\begin{array}{l}\text { Ziziphus joazeiro Mart. } \\
\text { Tocoyena sellowiana (Cham. \& Schltdl.) }\end{array}$ & 73 & 0.98 & 0.05 & 1.96 & 0.19 & 0.005 & 0.036 & 0.28 & 0.09 \\
\hline K.Schum. & 46 & 0.98 & 0.05 & 1.96 & 0.19 & 0.003 & 0.017 & 0.26 & 0.07 \\
\hline $\begin{array}{l}\text { Indeterminate } 1 \\
\text { Senna macranthera (DC. ex Collad.) }\end{array}$ & 485 & 0.98 & 0.05 & 1.96 & 0.19 & 0.002 & 0.011 & 0.26 & 0.06 \\
\hline $\begin{array}{l}\text { H.S.Irwin \& Barneby } \\
\text { Myriopus rubicundus (Salzm. ex DC.) }\end{array}$ & 102 & 0.98 & 0.05 & 1.96 & 0.19 & 0.001 & 0.009 & 0.25 & 0.06 \\
\hline Luebert & 549 & 0.98 & 0.05 & 1.96 & 0.19 & 0.001 & 0.009 & 0.25 & 0.06 \\
\hline Varronia leucocephala (Moric.) J.S.Mill. & 467 & 0.98 & 0.05 & 1.96 & 0.19 & 0.001 & 0.006 & 0.25 & 0.06 \\
\hline Alibertia sp. & 304 & 0.98 & 0.05 & 1.96 & 0.19 & 0.001 & 0.005 & 0.25 & 0.06 \\
\hline Total & - & $1,827.42$ & 100 & $1,017.62$ & 100 & 14.488 & 100 & 300 & 200 \\
\hline
\end{tabular}

C. leprosum, dead specimens, and C. blanchetianus had the highest absolute density (AD) and relative density (RD) in the community structure, accounting for $43.8 \%$ of the total relative density. The highest absolute frequency (AF) and relative frequency (RF) were recorded for dead specimens sampled in the 51 plots, followed by C. leprosum (42), C. pyramidale (40), C. blanchetianus (39), M. glaziovii (37), A. urundeuva (28), C. monetaria (26), C. echioides and M. ophthalmocentra (23), L. auriculata and C. leptophloeos (22), and A. pyrifolium (17 plots). These 11 species and dead specimens accounted for $71.3 \%$ of the total relative frequency. With regard to absolute dominance (ADo) and relative dominance (RDo), C. leptophloeos $\left(1.96 \mathrm{~m}^{2}\right.$ basal area) and C. pyramidale $\left(1.84 \mathrm{~m}^{2}\right.$ basal area) were the most prominent species.

The highest importance values (IV) in descending order are listed, as follows: dead specimens, $C$. pyramidale, C. leprosum, C. blanchetianus, C. leptophloeos, M. glaziovii, A. urundeuva, C. monetaria, L. auriculata, C. echioides, and M. ophthalmocentra. These 10 species and dead specimens accounted for $74.1 \%$ of the total IV.

For species with one specimen per hectare, thirteen species were recorded in the Stream of the Mares, representing $28.3 \%$ of the total number. The number of dead plants (still standing) was $15.6 \%$ in relation to the total number of specimens sampled in the riparian forest. Considering the IV, dead specimens had high value (33.9\%); however, no localized disturbance was observed since dead specimens had a high frequency, occurring in all plots of the sampled area.

The average diameter of the sampled specimens was $10.1 \mathrm{~cm}$ and the maximum diameter found was 58.6

FLORESTA, Curitiba, PR, v. 50, n. 3, p. 1565 - 1574, jul/set 2020.

Lacerda, A. V. et.al.

ISSN eletrônico 1982-4688

DOI: $10.5380 /$ rf.v50 i3. 64520 
$\mathrm{cm}$ (C. leptophloeos). The frequency of DGL classes of the recorded trees and shrubs indicates a decrease in the number of specimens as the diameter increases (Figure 3A). Thus, of the 1,864 specimens sampled in the study stream, 1,581 (84.8\%) were classified in the first three diameter classes, and $999(53.6 \%)$ in the 3-6 cm class, whereas only one specimen was classified in the last diameter class.
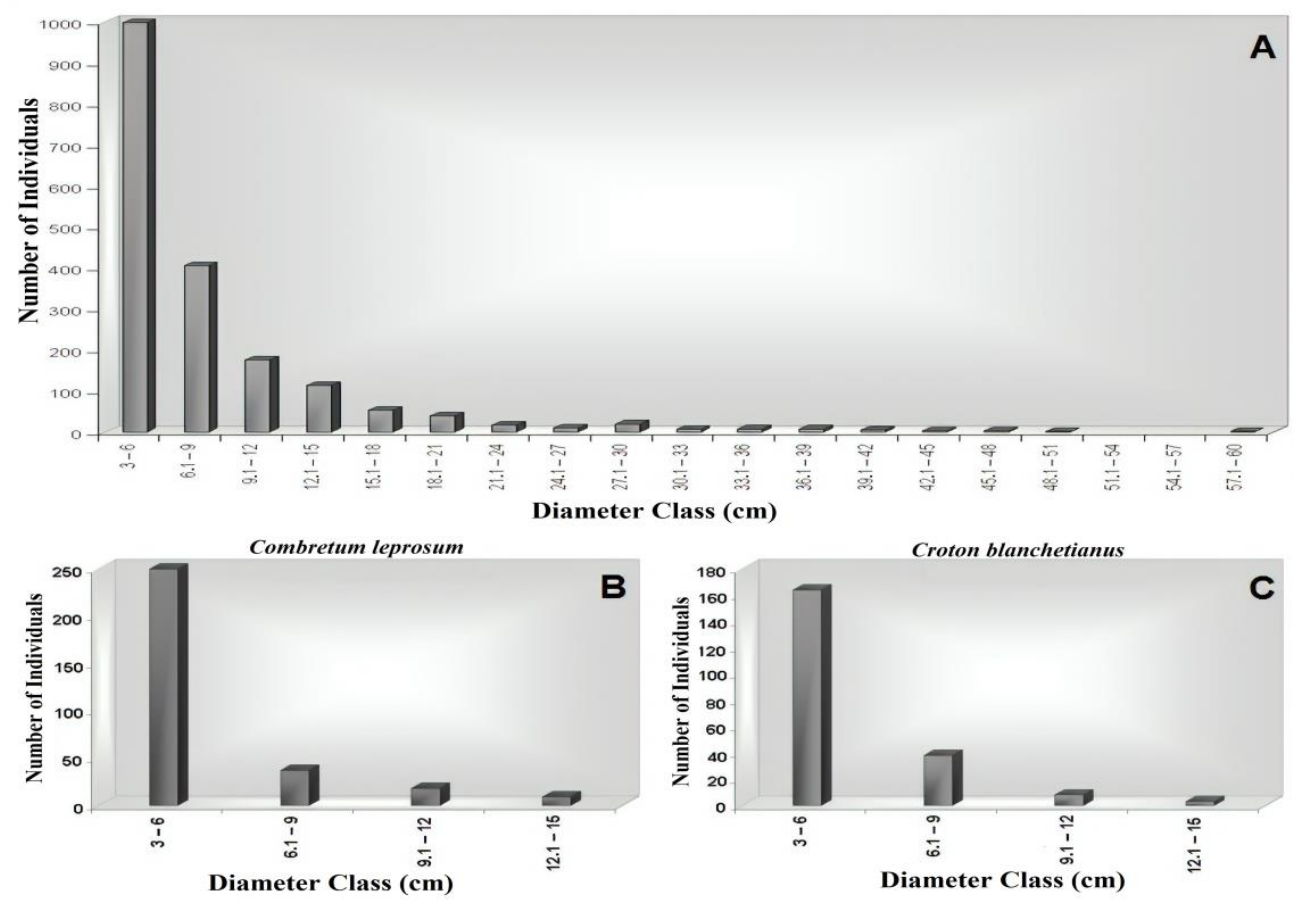

Croton blanchetianus

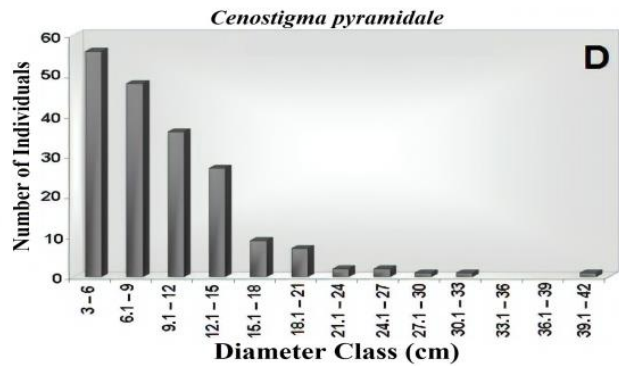

Figure 3. Distribution of specimens per diameter classes: (A) shrub-tree community sampled; (B, C, and D) species with more than $10 \%$ of representatives in the riparian forest of the Stream of the Mares, semi-arid region of Paraíba, Brazil.

Figura 3. Distribuição dos indivíduos por classes de diâmetro: (A) comunidade arbustivo-arbórea amostrada; (B, C e D) espécies com mais de $10 \%$ de representantes na área ribeirinha do riacho dos Mares, semiárido paraibano.

Regarding the diametric distribution, $C$. leprosum, $C$. blanchetianus, and $C$. pyramidale were the species that accounted for more than $10 \%$ of the total number of specimens (Figures 3B, 3C and 3D). All histograms welladjusted to the negative exponential model (inverted $\mathrm{J}$ ), with the highest number of specimens in the first class and a decrease toward the larger diameter classes. There were interruptions in the larger diameter classes for $C$. pyramidale, which may be related to diseases, senility, or exploitation.

The sampled specimens had an average height of $4.8 \mathrm{~m}$ and a maximum height of $14 \mathrm{~m}$ (for A. urundeuva) and a minimum height of $1 \mathrm{~m}$ (for $P$. gounellei and $S$. macrocarpa). According to the frequency distribution of height classes (Figure 4A), the most frequent classes were those consisting of trees and shrubs of which height was between 3-5 m. In addition, it was also found that the riparian vegetation accounted for a significant number of specimens over $8 \mathrm{~m}$ in height. 

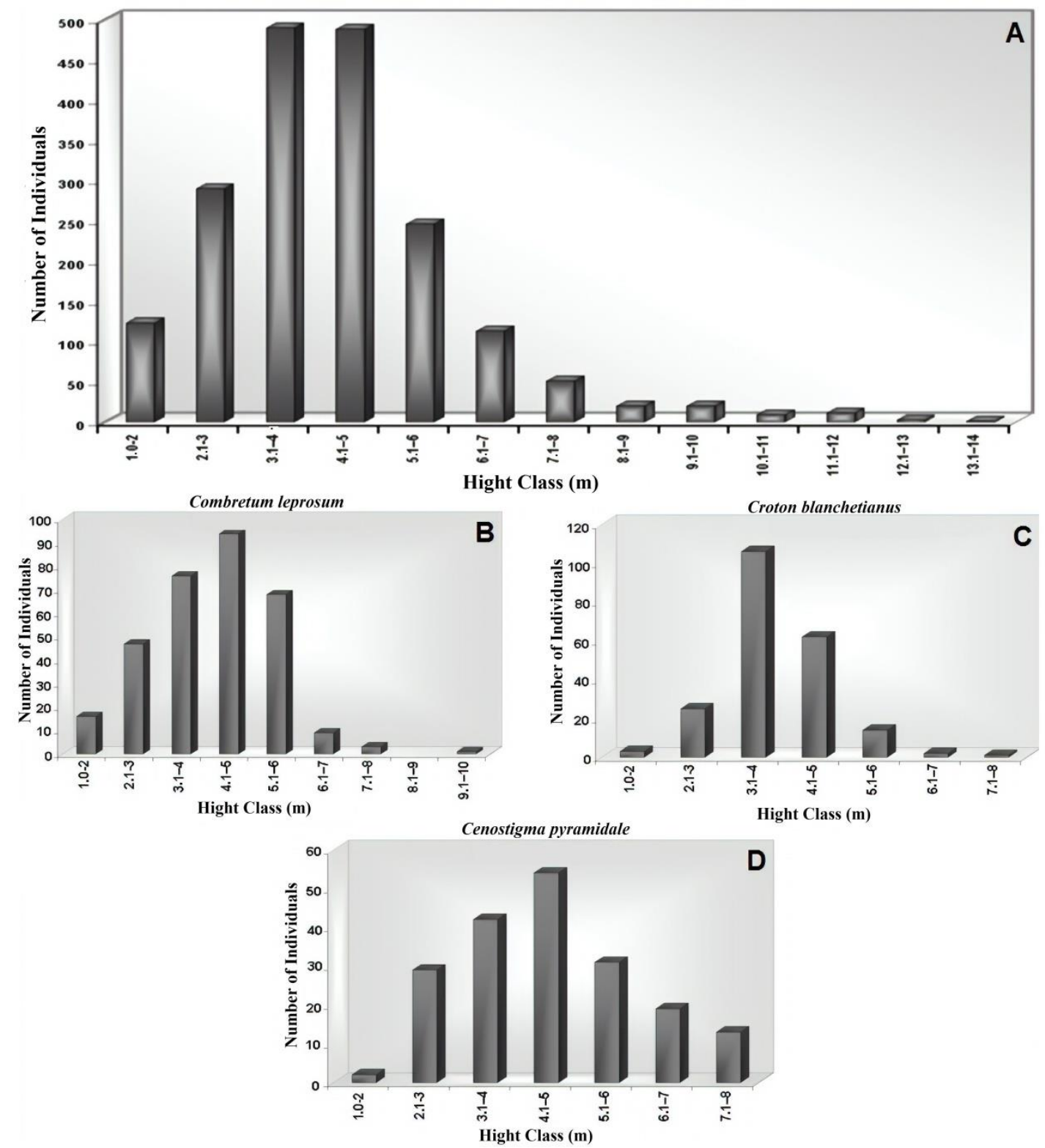

Figure 4. Distribution of specimens per height classes: (A) shrub-tree community sampled; (B, C, and D) species with more than $10 \%$ of representatives in the riparian forest of the Stream of the Mares, semi-arid region of Paraíba, Brazil.

Figura 4. Distribuição dos indivíduos por classes de altura: (A) comunidade arbustivo-arbórea amostrada; (B, C e D) espécies com mais de $10 \%$ de representantes na área ribeirinha do riacho dos Mares, semiárido paraibano.

Regarding the distribution of specimens, per height classes, of species with more than $10 \%$ of the total number of specimens (Figures 4B, 4C and 4D), C. leprosum had the most frequent class ranging from 4.1 to 5.0 $\mathrm{m}(29.9 \%$ of the total number of specimens). For $C$. blanchetianus, the distribution curves showed that height between 3.1 and $4.0 \mathrm{~m}$ was the most frequent class. For $C$. pyramidale, the most frequent class ranged from 4.1 to $5.0 \mathrm{~m} \mathrm{(28.4 \%} \mathrm{of} \mathrm{the} \mathrm{total} \mathrm{number} \mathrm{of} \mathrm{specimens).}$

Diversity and equability values were 2.77 nats.ind. ${ }^{-1}$ and 0.72 , respectively. 


\section{DISCUSSION}

The sampling sufficiency curve showed a stabilization from plot 29. According to Muller-Dumbois and Ellenberg (1974), this behavior indicates that the most common plant species, responsible for physiognomy, were sufficiently sampled. In addition, the Jackknife richness estimator of first order for the study area was $\mathbf{5 8 . 7 4}$ species; therefore, close to the value found.

In a study performed in a riparian area of Caatinga in the "Cariri Paraibano", Lacerda and Barbosa (2018) recorded 1,623 living and 215 standing dead specimens, distributed in 41 species, 36 genera, and 19 families. The total number of surveyed species was also higher than that found by Trovão et al. (2010) in a Caatinga riparian forest, semi-arid region of Paraíba.

Regarding the families, Euphorbiaceae also stood out in a study on a riparian forest in the semi-arid region of Paraíba (LACERDA; BARBOSA, 2018). Sabino et al. (2016) also recorded a higher number of specimens for Fabaceae and Euphorbiaceae in areas of Caatinga in Paraíba.

C. pyramidale also stood out with a high IV in studies conducted by Guedes et al. (2012) and Sabino et al. (2016) in the Caatinga. Lacerda and Barbosa (2018) also recorded the highest IV for this species in a Caatinga riparian system in the "Cariri Paraibano". According to some authors such as Rodrigues et al. (2003), many species surveyed in riparian areas are shared with Caatinga forest formations, thus characterizing a wide adaptation to the different ecosystems in the region.

A high number of species occurring with only one specimen was recorded. This may be related to a high diversity of flora and a low density of populations. In an associated way, this data also reflects a concern with the protective factors in riparian systems and their biological resources, which if severely degraded may compromise factors of existence of species with a low number of specimens.

The high IV recorded for dead specimens may be indicative of the high mortality rate due to the recurring disturbances that occur in the time and space function in riparian ecological systems in the semi-arid region of Brazil. Thus, according to Martins (1991), the mortality of species may be related to some factors such as winds, storms, fall of large branches, and even diseases, anthropogenic disturbances, or senility. With regard to the study riparian area and its degree of conservation, the high number of dead specimens recorded here is an intrinsic feature of riparian systems, which are characterized by the heterogeneity of biotic and abiotic components of these areas. Therefore, standing dead specimens play important functional roles in riparian ecosystems, forming important relationship structures with biotic components and participating in nutrient cycling.

Regarding the inverted J-curve recorded for diameter classes, some authors such as Martins (1991) argue that equilibrium populations have diameter classes in a decreasing geometric series (inverted J). For Assmann (1970), a high concentration of individuals in the smallest diameter classes is defined as a typical pattern of unevenaged natural forest. Machado et al. (2004) state that most of the studies on native tree-shrub communities in autochthonous forests have a diametric distribution in an inverted J-curve or negative exponential model. It is noteworthy that a similar result was observed in a study conducted by Sabino et al. (2016) in the Caatinga.

The highest number of specimens in the 3-12 cm diameter classes was also found by Pereira Júnior $e t$ al. (2012) in a survey performed in the Caatinga. Thus, there was a natural tendency for a higher concentration of specimens in the smallest diameter classes. Interruptions in the highest diameter classes indicate a discontinuous growth, i.e., plant growth must have been interrupted by some factors such as prolonged and severe drought, diseases, senility, or selective cutting of large-sized specimens for timber purposes.

The diametric distribution for species with more than $10 \%$ of the total number of specimens adjusted to the inverted $\mathbf{J}$ model, evidencing the occurrence of a continuous supply of seedlings to the largest diameter classes. Thus, these species have had a complete life cycle and the population can be considered in equilibrium in the environment. For $C$. pyramidale, there were interruptions in the largest diameter classes, which may be related to diseases, senility, or exploitation.

The significant number of specimens over $8 \mathrm{~m}$ in height is discussed by Araújo et al. (2005), who explain that a higher soil moisture content in riparian environments also favors the occurrence of larger woody plants.

The diversity index recorded in this study is higher than that found by Lacerda and Barbosa (2018) and Trovão et al. (2010) in a riparian forest in the Caatinga in Paraíba. Based on studies conducted in solid ground natural systems in the Caatinga, the values presented in this study were also higher than those found by Guedes et al. (2012), Pereira Júnior et al. (2012), Barbosa et al. (2012), and Sabino et al. (2016).

FLORESTA, Curitiba, PR, v. 50, n. 3, p. 1565 - 1574, jul/set 2020

Lacerda, A. V. et.al.

ISSN eletrônico 1982-4688

DOI: $10.5380 /$ rf.v50 i3. 64520 


\section{CONCLUSIONS}

- The number of species recorded in this study was higher than those from surveys in riparian forest areas in the semi-arid region of Paraíba. C. pyramidale stood out with the highest importance value. This species is also prominently cited in other studies carried out in the Caatinga.

- Dead specimens had high IV; however, no localized disturbance was observed since dead plants (still standing) had a high frequency, occurring in all sampled plots.

- According to the frequency of diameter classes, the number of specimens decreases as the diameter increases and this is a characteristic of native tree-shrub communities of autochthonous forests.

- The diversity index recorded here was higher than those found in other riparian forest environments in the Caatinga.

\section{REFERENCES}

APG III. An update of the Angiosperm Phylogeny Group Classification for the orders and families of flowering plants: APG III. Botanical Journal of Linnean Society, London, v. 161, p. 105-121, 2009.

ARAÚJO, E. L.; SILVA, K. A.; FERRAZ, E. M. N.; SAMPAIO, E. V. S. B.; SILVA, S. I. Diversidade de herbáceas em microhabitats rochoso, plano e ciliar em uma área de caatinga, Caruaru, PE, Brasil. Acta Botânica Brasilica, Belo Horizonte, v. 19, n. 2, p. 285-294, 2005.

ASSMANN, E. The principles of forest yield: studies in the organic production, structure, incremente and yield of forest stands. Braunschweig: Pergamon Press, 1970, $506 \mathrm{p}$.

AVILA, A. L.; ARAUJO, M. M.; LONGHI, S. J.; GASPARIN, E. Caracterização da vegetação e espécies para recuperação de mata ciliar, Ijuí, RS. Ciência Florestal, Santa Maria, v. 21, n. 2, p. 251-260, 2011.

BARBOSA, M. D.; MARANGON, L. C.; FELICIANO, A. L. P.; FREIRE, F. J.; DUARTE, G. M. T. Florística e fitossociologia de espécies arbóreas e arbustivas em uma área de caatinga em Arcoverde, PE, Brasil. Revista Árvore, Viçosa, v. 36, n. 5, p. 851-858, 2012.

BRACKMANN, C. E.; FREITAS, E. M. Florística arbórea e arbustiva de um fragmento de Mata Ciliar do arroio Boa Vista, Teutônia, RS, Brasil. Hoehnea, Boa vista, v. 40, n.2, p. 365-372, 2013.

CAIN, S. A.; CURTIS, G. M. Manual of vegetation analysis. New York: Hafuer, 1959. 325 p.

CHAVES, A. D. C. G.; SANTOS, R. M. S.; SANTOS, J. O.; FERNANDES, A. A.; MARACAJÁ, P. B. A importância dos levantamentos florísticos e fitossociológico para a conservação e preservação das florestas. Revista ACSA - Agropecuária Científica no Semiárido, Campina Grande, v. 9, n. 2, p. 43-48, 2013.

CIENTEC - Consultoria e Desenvolvimento de Sistemas. Mata Nativa 4: Software para inventário de florestas nativas. Viçosa, MG, 2016.

GUEDES, R. S.; ZANELLA, F. C. V.; COSTA, J. E. V.; SANTANA, G. M.; SILVA, J. A. Caracterização florístico-fitossociológica do componente lenhoso de um trecho de Caatinga no semiárido paraibano. Revista Caatinga, Mossoró, v. 25, n. 2, p. 99-108, 2012.

IBGE - Instituto Brasileiro de Geografia e Estatística. Manual técnico da vegetação brasileira. Rio de Janeiro: IBGE, 2 ed. 2012, 275 p.

JARDIM, F. C. S.; SENA, J. R. C.; MIRANDA, I. S. Dinâmica e estrutura da vegetação com $5 \mathrm{~cm}$ em torno de clareiras da exploração florestal seletiva, em Moju, Pará. Revista de ciências agrárias, Belém, v. 49, n. 1, p. 4152, 2008.

LACERDA, A. V.; BARBOSA, F. M. Fitossociologia da vegetação arbustivo-arbórea em uma área de mata ciliar no semiárido paraibano, Brasil. Gaia Scientia, João Pessoa, v. 12, n. 2, p. 34-43, 2018.

MACHADO, E. L. M.; OLIVEIRA-FILHO, A. T.; CARVALHO, W. A. C.; SOUZA, J. S.; BORÉM, R. A. T.; BOTEZELLI, L. Análise comparativa da estrutura e flora do compartimento arbóreo-arbustivo de um remanescente florestal na fazenda Beira Lago, Lavras, MG. Revista Árvore, Viçosa, v. 28, n. 4, p. 499-516, 2004.

MAGURRAN, A. E. Ecological diversity and its measurement. Princeton: Princeton University Press, 1988, $167 \mathrm{p}$.

MARTINS, F. R. Estrutura de uma floresta mesófila. Campinas: UNICAMP, 2 ed. 1991, 246 p.

FLORESTA, Curitiba, PR, v. 50, n. 3, p. 1565 - 1574, jul/set 2020.

Lacerda, A. V. et.al.

ISSN eletrônico 1982-4688

DOI: $10.5380 /$ rf.v50 i3. 64520 
MUELLER-DOMBOIS, D.; ELLENBERG, H. Aims and methods of vegetation ecology. New York: John Wiley \& Sons, 1974, 547 p.

OLIVEIRA, E. B. D.; MARANGON, L. C.; FELICIANO, A. L.; FERREIRA, R. L.; RÊGO, P. L. Estrutura fitossociológica de um fragmento de mata ciliar, Rio Capibaribe Mirim, Aliança, Pernambuco. Revista Brasileira de Ciências Agrárias, Recife, v. 4, n. 2, p. 167-172, 2009.

PEREIRA JÚNIOR, L. R.; DE ANDRADE, A. P.; ARAÚJO, K. D. Composição florística e fitossociológica de um fragmento de caatinga em Monteiro, PB. Holos, Natal, v. 6, ano 28, p. 73-87, 2012.

PIELOU, E. C. Ecological diversity. New York: Jonh Wiley \& Sons, 1975, 165 p.

REFLORA. Flora do Brasil 2020 em construção [Internet]. 2016 [cited 2016 May 18]. Available from: https://bit.ly/2ITnPXi

RODRIGUES, L. A; CARVAlHO, D. A; OLIVEIRA-FILHO, A. T.; BOTREL, R. T.; SILVA E. A. Florística e estrutura da comunidade arbórea de um fragmento florestal em Luminárias, MG. Acta Botanica Brasilica, v. 17, n. 1, p. 71-87, 2003.

RODRIGUES, R. R.; LEITÃO-FILHO, H. F. Matas ciliares: conservação e recuperação. São Paulo: EDUSP/FAPESP, 2009, 320 p.

SABINO, F. G. S.; CUNHA, M. C. L.; SANTANA, G. M. Estrutura da Vegetação em Dois Fragmentos de Caatinga Antropizada na Paraíba. Floresta e Ambiente, Rio de Janeiro, v. 23, n. 4, p. 487-497, 2016.

TROVÃO, D. M. B. M; FREIRE, A. M.; MELO, I. J. M. M. Florística e fitossociologia do componente lenhoso da mata Ciliar do Riacho de Bodocongó, Semiárido paraibano. Revista Caatinga, Mossoró, v. 23, n. 2, p. 78-86, 2010 . 